Research article

Open Access

\title{
PD 0332991, a selective cyclin D kinase 4/6 inhibitor, preferentially inhibits proliferation of luminal estrogen receptor-positive human breast cancer cell lines in vitro
}

\author{
Richard S Finn1, Judy Dering1, Dylan Conklin 1, Ondrej Kalous ${ }^{1}$, David J Cohen ${ }^{1}$, Amrita J Desai1, \\ Charles Ginther ${ }^{1}$, Mohammad Atefi' ${ }^{1}$ Isan Chen², Camilla Fowst ${ }^{3}$, Gerret Los ${ }^{2}$ and \\ Dennis J Slamon ${ }^{1}$
}

\author{
1'Department of Medicine, Division of Hematology/Oncology, Geffen School of Medicine at UCLA, 10833 Le Conte Ave, 11-934 Factor Bldg, Los \\ Angeles, CA 90095, USA \\ 2Pfizer Global Research and Development, Pfizer Inc., 10724 Science Center Drive, San Diego, CA 92121, USA \\ 3Pfizer Oncology BU, Clinical Development, Pfizer Inc., Via Lorenteggio 257, Milan 20152, Italy \\ Corresponding author: Richard S Finn, rfinn@mednet.ucla.edu
}

Received: 19 Jun 2009 Revisions requested: 2 Jul 2009 Revisions received: 7 Sep 2009 Accepted: 29 Oct 2009 Published: 29 Oct 2009

Breast Cancer Research 2009, 11:R77 (doi:10.1186/bcr2419)

This article is online at: http://breast-cancer-research.com/content/11/5/R77

(C) 2009 Finn et al.; licensee BioMed Central Ltd.

This is an open access article distributed under the terms of the Creative Commons Attribution License (http://creativecommons.org/licenses/by/2.0), which permits unrestricted use, distribution, and reproduction in any medium, provided the original work is properly cited.

\begin{abstract}
Introduction Alterations in cell cycle regulators have been implicated in human malignancies including breast cancer. PD 0332991 is an orally active, highly selective inhibitor of the cyclin D kinases (CDK)4 and CDK6 with ability to block retinoblastoma $(\mathrm{Rb})$ phosphorylation in the low nanomolar range. To identify predictors of response, we determined the in vitro sensitivity to PD 0332991 across a panel of molecularly characterized human breast cancer cell lines.

Methods Forty-seven human breast cancer and immortalized cell lines representing the known molecular subgroups of breast cancer were treated with PD 0332991 to determine $I_{50}$ values. These data were analyzed against baseline gene expression data to identify genes associated with PD 0332991 response.
\end{abstract}

Results Cell lines representing luminal estrogen receptorpositive $(E R+)$ subtype (including those that are HER2 amplified) were most sensitive to growth inhibition by PD 0332991 while nonluminal/basal subtypes were most resistant. Analysis of variance identified 450 differentially expressed genes between sensitive and resistant cells. $p R b$ and cyclin $D_{1}$ were elevated and CDKN2A ( $p 16$ ) was decreased in the most sensitive lines. Cell cycle analysis showed $G_{0} / G_{1}$ arrest in sensitive cell lines and Western blot analysis demonstrated that $\mathrm{Rb}$ phosphorylation is blocked in sensitive lines but not resistant lines. PD 0332991 was synergistic with tamoxifen and trastuzumab in ER+ and HER2-amplified cell lines, respectively. PD 0332991 enhanced sensitivity to tamoxifen in cell lines with conditioned resistance to ER blockade.

Conclusions These studies suggest a role for CDK4/6 inhibition in some breast cancers and identify criteria for patient selection in clinical studies of PD 0332991.

\section{Introduction}

Breast cancer is a worldwide health concern with approximately 1,000,000 million new cases each year [1]. Significant advances have been made in our understanding of this malignancy and several molecular subtypes of breast cancer have been characterized [2-4]. This molecular understanding has paved the way for the development of new agents that target pathogenic molecular alterations that drive tumor cell growth while sparing patients many of the traditional toxicities associated with chemotherapy. Ubiquitous to all cancer types is abnormal proliferation with dysregulation of normal cell cycle control [5]. For this reason, inhibitors of key cell cycle regulators are attractive targets for novel cancer therapeutics [6]. Successful clinical development of this class of agents, however, will require some understanding of which subgroup of

ANOVA: analysis of variance; CDK: cyclin D kinase; $\mathrm{Cl}$ : combination index; DMEM: Dulbecco's modified Eagle's medium; ER: estrogen receptor; FBS: fetal bovine serum; FITC: fluorescein isothiocyanate; $I_{50}$ : concentration that inhibits growth by $50 \%$ of control; PBS: phosphate-buffered saline; PSF: 1\% penicillin G-streptomycin-fungizone solution; Rb: retinoblastoma. 
patients will be more likely to benefit from these targeted interventions.

Under normal control, the cell cycle functions as a tightly regulated and predictable process consisting of several distinct phases: $G_{0}$ (quiescence) followed by $G_{1}$ (pre-DNA synthesis), $S$ (DNA synthesis), $G_{2}$ (pre-division), and $M$ (cell division). The careful regulation of this system is of fundamental importance, and dysregulation can result in several disease processes including cancer. The progression from $G_{1}$ to $S$ is a key checkpoint in protecting the cell from abnormal replication. Key to passage through this restriction point is the interaction between the cyclin-dependent kinases (CDKs) and cyclin proteins. CDKs are a subgroup of serine/threonine kinases that play a key role in regulating cell cycle progression by associating with cyclins. Hyperphosphorylation of the retinoblastoma $(\mathrm{Rb})$ gene product $\mathrm{pRb}$ is mediated in early $\mathrm{G}_{1}$ by CDK4 and CDK6 interacting with cyclin $D_{1}$. This results in pRB inactivation and release of transcription factors that allow progression to the $S$ phase. Negative regulators of CDK4/6-cyclin activity include the INK4 family (p16, p15, p18, p19) [7].

Several studies have identified alterations of cell cycle regulators in human breast cancer (reviewed in $[8,9]$ ) and provide a rationale for a potential therapeutic role for CDK4/6 inhibition in this tumor type. Amplification of the cyclin $D_{1}$ gene has been identified in approximately 15 to $20 \%$ of human breast cancers $[10,11]$ while overexpression of the protein has been demonstrated in a higher percentage [12,13]. The prognostic significance of cyclin $D_{1}$ overexpression is not clear; some studies suggest it is a dominant oncogene associated with poor clinical outcomes [11,14-16], while other studies suggest it is associated with a more indolent, estrogen receptor (ER)-positive phenotype $[17,18]$. In addition, studies have associated cyclin D amplification with resistance to tamoxifen $[19,20]$. While the interaction between CDK4/6 and cyclin $D_{1}$ suggests their interdependence, cyclin $D_{1}$ has been found to function independently of CDK4/6 in supporting proliferation by directly activating ER $[21,22]$. Finally, loss of function of $p R b$ has been described in 20 to $35 \%$ of breast cancers (reviewed in [23]).

The majority of CDK targeted agents to date have not focused on CDK4/6 targeting but rather on CDK1/2 targeting. Consequently the most advanced agents in development are aimed at these targets $[24,25]$. Further, limited data exist regarding the preclinical activity of CDK4/6 inhibitors in breast cancer. PD 0332991 is an orally active potent and highly selective inhibitor of CDK4 and CDK6 kinases, which in low nanomolar concentrations blocks pRb phosphorylation - subsequently inducing $G_{1}$ arrest in sensitive cell lines [26-29]. Preclinical studies have demonstrated that PD 0332991 induces $G_{1}$ arrest in primary bone marrow cells ex vivo and prevents tumor growth in disseminated human myeloma xenografts [30].
Based on the above biology, we hypothesized that there might be a molecular subgroup of human breast cancers that would be dependent on CDK4/6 function and would be likely to respond to this agent. Previous studies have demonstrated that in vitro large-panel analyses of molecularly characterized breast cancer cell lines can offer insight into the molecular heterogeneity of the clinical disease [31,32]. To identify potential biomarkers of response to PD 0332991 and to assist in patient selection and clinical development, we therefore evaluated the effects of PD 0332991 in a panel of 47 human breast cancer and immortalized breast cell lines growing in vitro.

\section{Materials and methods Cell lines, cell culture, and reagents}

The cell lines used in the analysis include MDA-MB-415, MDA-MB-134, HCC-1500, ZR-75-30, HCC-202, HCC1419, HCC-38, HCC-70, HCC-1187, HCC-1806, HCC1937, HCC-1954, MDA-MB-436, HCC-1569, Hs578t, HCC1143, MDA-MB-175, BT-474, SK-BR-3, MDA-MB-361, UACC-893, UACC-812, UACC-732, T-47D, MDA-MB-453, MDA-MB-468, CAMA-1, MDA-MB-157, MCF-7, MDA-MB435, ZR-75-1, BT-20, MDA-MB-231, BT-549, DU4475, HCC-1395, HCC-2218, 184A1, 184B5 and MCF-10A, and were obtained from American Type Culture Collection (Rockville, MD, USA). The cell lines EFM-192A, KPL-1, EFM-19, COLO-824 and CAL-51 were obtained from the German Tissue Repository DSMZ (Braunschweig, Germany), and the cell lines SUM-190 and SUM-225 were obtained from the University of Michigan (Ann Arbor, MI, USA).

MDA-MB-134, MDA-MB-415, MDA-MB-436, MDA-MB-175, UACC-893, UACC-812, and MDA-MB-157 cells were cultured in L15 medium supplemented with 10\% heat-inactivated FBS, $2 \mathrm{mmol} / \mathrm{l}$ glutamine and 1\% penicillin G-streptomycinfungizone solution (PSF) (Irvine Scientific, Santa Ana, CA, USA). CAL-51, KPL-1, and Hs578t cells were grown in DMEM (Cellgro, Manassas, VA, USA) supplemented with $10 \%$ heat-inactivated FBS and PSF, as above. SUM-190 and SUM-225 cells were cultured in HAM's F12 supplemented with $5 \%$ heat-inactivated FBS, PSF, $5 \mathrm{mg} / \mathrm{ml}$ insulin and $1 \mathrm{mg} /$ $\mathrm{ml}$ hydrocortisone. 184A1, 184B5, and MCF $10 \mathrm{~A}$ cells were grown in a 50/50 mix of mammary epithelial basal medium (MCDB 170) (US Biological, Swampscott, MA, USA) supplemented with $1.5 \mathrm{ml} / \mathrm{l}$ bovine pituitary extract (Invitrogen, Carlsbad, CA, USA), $20 \mu \mathrm{l} / \mathrm{l}$ epidermal growth factor (Invitrogen), $10 \mathrm{ml}$ insulin (Sigma, Saint Louis, MO, USA), $1 \mathrm{ng} / \mathrm{ml}$ cholera toxin (Calbiochem, San Diego, CA, USA), $0.5 \mathrm{mg} / \mathrm{l}$ hydrocortisone (Sigma), and RPMI 1640 supplemented with 10\% heat-inactivated FBS, $2 \mathrm{mmol} / \mathrm{l}$ glutamine, and 1\% PSF. The remaining cell lines were cultured in RPMI 1640 (Cellgro) supplemented with 10\% heat-inactivated FBS, $2 \mathrm{mmol} / \mathrm{l}$ glutamine, and 1\% PSF. A tamoxifen-resistant MCF7 cell line was developed after serial passage in RPMI 1640 without phenol red (Invitrogen) supplemented with 10\% charcoal- 
stripped FBS (Fisher Scientific, Pittsburgh, PA, USA) and 2 $\mathrm{mmol} / \mathrm{l}$ glutamine, and PSF.

\section{Transcript microarray analyses}

Briefly, cells were grown to log phase and then RNA was extracted using the RNeasy Kit (Qiagen, Valencia, CA, USA). The purified RNA was eluted in 30 to $60 \mu$ diethylpyrocarbonate (DEPC) water and the quantity of RNA measured by spectral analysis using the Nanodrop Spectrophotometer (NanoDrop Products, Wilmington, DE, USA). RNA quality was determined by separation of the RNA via capillary electrophoresis using the Agilent 2000 Bioanalyzer (Agilent Technologies, Santa Clara, CA, USA). Microarray hybridizations of 51 breast cell lines were performed using the Agilent Human $1 \mathrm{~A}$ V1 array.

Characterization of individual breast cancer cell line transcripts was performed by comparison with a breast cell line mixed reference pool of RNA and was conducted on a single slide in which the cell line mixture RNA was labeled with cyanine-3 and RNA from the individual cell line was labeled with cyanine-5. The mixed reference cRNA pool consisted of equal amounts of cRNA from nine breast cancer cell lines and one immortalized breast cell line selected to be representative of the full spectrum of breast cancer subtypes based on their expression of specific molecular markers - for example, ESR1, HER2, epidermal growth factor receptor, cytokeratins, and so forth - as well as growth characteristics. The reference cRNA pool includes RNA from 184B5, MDA-MB-468, MDA-MB157, MDA-MB-231, MDA-MB-175, CAMA-1, MCF-7, MDAMB-361, SK-BR-3, and DU4475 cell lines.

Microarray slides were read using an Agilent Scanner, and Agilent Feature Extraction software version 7.5 was used to calculate gene expression values. The feature extracted files were imported into the Rosetta Resolver ${ }^{\circledR}$ system version 7.1 for gene expression data analysis (Rosetta Biosoftware, Seattle, WA, USA). The intensity ratios between the cell line sample and mixed reference calculated for each sequence were computed according to the Agilent error model. A particular sequence was considered differentially expressed if the calculated $p$-value of change was $P \leq 0.01$. These data are available with accession number [GEO:GSE18496].

\section{Proliferation assays}

Cells were seeded in duplicate at 5,000 to 10,000 cells per well in 24-well plates. The day after plating, PD 0332991 was added at $1 \mu \mathrm{M}$ and twofold dilutions over six concentrations were performed to generate a dose-response curve. Control wells without drug were also seeded. Cells were counted on day 1 when the drug was added as well as after 6 days when the experiment ended. After trypsinization, cells were placed in Isotone solution and counted immediately using a Coulter Z2 particle counter (Beckman Coulter Inc., Fullerton, CA, USA).
Suspension lines were counted using a Coulter Vi-Cell counter (Beckman Coulter Inc.).

Growth inhibition was calculated as a function of the number of generations inhibited in the presence of PD 0332991 versus the number of generations over the same time course in the absence of PD 0332991. In addition, lethality was defined as any decrease in cell number in treated wells versus the baseline number of cells pre-treatment at day 1 of exposure.

For tamoxifen studies with the MCF7 tamoxifen-resistant cell line, proliferation studies were performed as above except cells were plated without FBS and were supplemented with $0.5 \mathrm{nM} \beta$-estradiol (Sigma). Proliferation assays were then performed as above.

\section{Multiple drug effects analysis}

Similar to above, the ER-positive cell lines MCF-7, T47-D, and EFM-19 were plated and treated with PD 0332991 alone, with 4-hydroxytamoxifen (Sigma) alone, or with the combination, in duplicate, over six twofold dilutions at a fixed molar ratio. For combination studies with trastuzumab, BT-474, EFM-192A, and MDA-361 lines were plated as above and treated with PD 0332991 alone, with trastuzumab (Genentech, South San Francisco, CA, USA) alone, or with the combination, in duplicate, over six twofold dilutions at a fixed molar ratio.

For each assay, the log of the fraction growth inhibition was plotted against the log of drug concentration, and the linear regression curve fit correlation coefficient ( $r$ value) was calculated. Multiple drug effect analysis was performed using computer software as previously described [33].

Combination index $(\mathrm{Cl})$ values were derived from parameters of the median effects plots, and statistical tests were applied (unpaired, two-tail Student $t$ test) to determine whether the mean $\mathrm{Cl}$ values at multiple concentrations were significantly different from $\mathrm{Cl}=1$. In this analysis, synergy is defined as $\mathrm{Cl}$ values significantly lower than 1.0 , antagonism as $\mathrm{Cl}$ values significantly higher than 1.0, and additivity as $\mathrm{Cl}$ values equal to 1.0 . All $\mathrm{Cl}$ values were calculated using the conservative assumption of mutually nonexclusive drug interactions. All experiments were carried out at least twice. Combination studies were performed as above with the MCF7 tamoxifen-resistant clones with addition of estrogen back to the media at the time of the experiment (as described in cell culture above).

\section{Western blot analysis}

Cells in log-phase growth were treated with 100 nM PD 0332991 and were harvested at various timepoints by washing in PBS and lysis at $4^{\circ} \mathrm{C}$ in RIPA lysis buffer. Insoluble material was cleared by centrifugation at $10,000 \times g$ for 10 minutes and protein was quantitated using bicinchoninic (BCA) (Pierce Biochemicals, Rockford, IL, USA). Protein content was resolved by SDS-PAGE electrophoresis, and was transferred 
to nitrocellulose membranes (Invitrogen). Total pRb expression was detected using a rabbit polyclonal antibody to $\mathrm{pRb}$ (Abcam, Cambridge, MA, USA). Rb phosphorylation was detected using rabbit polyclonal antibody to phospho-serine 780 (Cell-signaling, Danvers, MA, USA). Blots were washed and incubated with a goat-anti-rabbit IgG horseradish peroxidase conjugate (Upstate, Bellerica, MA, USA), developed using ECL Plus chemifluorescent reagent (Amersham Biosciences, Pistcataway, NJ), and imaged using chemifluorescence.

\section{Cell cycle analysis and apoptosis studies}

Effects of PD 0332991 on the cell cycle were assessed using Nim-DAPI staining (NPE Systems, Pembroke Pines, FL, USA). Cells were plated evenly in control and experimental wells, were allowed to grow to log phase and were then treated with 100 nM PD 0332991 for the defined times. To perform cell cycle analysis, cells were washed with PBS; then trypsin was applied to release cells, which were then centrifuged at $10,000 \times g$ for 5 minutes. Supernatant was aspirated and cells were then resuspended in $100 \mu \mathrm{l} \mathrm{Nim-DAPI} \mathrm{(NPE} \mathrm{Sys-}$ tems) and gently vortexed.

Cells were analyzed with UV using a Cell Lab Quanta SC flow cytometer (Beckman-Coulter Inc.). Apoptosis assays were performed using an Annexin V-FITC apoptosis detection kit (MBL, Woburn, MA, USA) and flow cytometry. Cells were plated and treated as for cell cycle studies and were exposed to $100 \mathrm{nM}$ PD 0332991 for 5 days. After incubation, cells were processed as directed in the kit and were analyzed using a FITC signal detector and propidium iodide detector using a Cell Lab Quanta SC flow cytometer.

\section{Statistical methods}

Growth response to PD 0332991 and molecular subtype classification data were entered into the Statistica data analysis system version 8.0 (StatSoft Inc., Tulsa, OK, USA). The Pearson chi-square test was used to assess the relationship between response and subtype.

Breast cell lines were profiled on the Agilent Human 1A V1 platform that contains 17,086 probes including known genes and ESTs. The Resolver system analysis of variance (ANOVA) and hierarchical cluster analysis of the breast cell line expression profiles were used to compare the most sensitive cell lines $\left(n=21, I C_{50}<150 \mathrm{nM}\right)$ and the most resistant cell lines $\left(n=12, I_{50}>1,000 n M\right)$. All ANOVAs were performed using the Benjamini-Hochberg False Discovery Rate (FDR) multiple test correction and a statistical cutoff value for sequences of a twofold change in at least three experiments. The criteria used to determine differentially expressed genes were $P<0.05$ with a difference between average expression for each group of at least $|0.2|$. Sequence sets were compared using the Venn Diagram tool in the Resolver system. The two-dimensional cluster analysis was performed using an agglomerative hierarchical clustering algorithm based on the cosine correlation similarity metric.

\section{Results \\ PD 0332991 inhibits growth of luminal ER-positive as well as HER2-amplified breast cancer cell lines}

A total of 44 human breast cancer cell lines and three immortalized breast epithelial lines were categorized as representing luminal or basal breast cancer subtypes based on the relative gene expression of cytokeratin 8/cytokeratin 18 and cytokeratin $5 /$ cytokeratin 17 , respectively $[31,32]$.

Several cell lines were further classified as representing breast cancers that had undergone an epithelial-to-mesenchymal transition based on their expression of vimentin and the loss of cytokeratin expression. Some cell lines that demonstrated mixed cytokeratin expression were classified as primarily basal due to the lack of expression of several additional well-characterized luminal markers, including ER, E-cadherin (CDH1), and GATA3. The calculated $I C_{50}$ for each cell line and its molecular classification as well as the ER status and HER2 amplification status was determined (Table 1 and Figure 1).

There was a statistically significant correlation between molecular subtype and sensitivity to PD $0332991\left(\chi^{2}<0.05\right)$. The subtypes most sensitive to growth inhibition by PD 0332991 were ER-positive. In addition, 10/16 HER2-amplified cell lines were sensitive. PD 0332991 inhibited growth in a cytostatic manner in these cells with no lethality observed (data not shown).

\section{Identification of differentially expressed genes and sensitivity to PD 0332991}

Gene expression profiles were used to identify genes associated with response to PD 0332991 . A set of 450 differentially expressed genes $(P<0.05$, |sensitive group average - resistant group average $\mid \geq 0.2$ ) was identified, where 253 genes were upregulated in sensitive cell lines and 197 genes were upregulated in resistant lines. Hierarchical clustering of the 43 cell lines across these 450 differentially expressed genes was performed (Figure 2).

A significant overlap was found between the gene set associated with response to PD 0332991 and the gene set that defines breast cancer cell subtypes. Of the genes more highly expressed in the sensitive cell lines, 193/253 (76\%) are luminal markers and 0/253 are nonluminal markers. In the resistant gene set, 117/197 (59\%) are nonluminal markers and 0/197 are luminal markers. RB1, cyclin $\mathrm{D}_{1}$, and CDKN2A ( $\left.p 16\right)$ were differentially expressed - with higher levels of RB1 and cyclin $D_{1}$, and lower levels of $p 16$, in the sensitive group. Of note, these three genes are cyclin related and are not in the breast cell type gene set. 
Figure 1

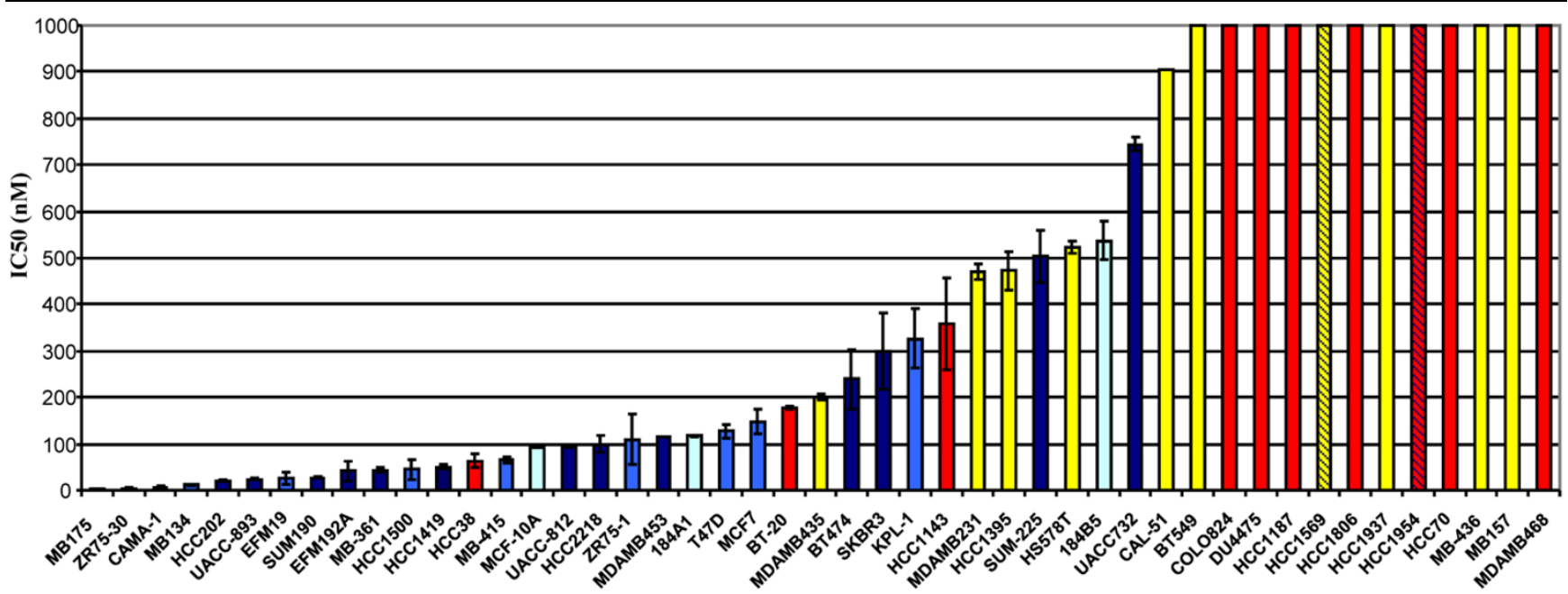

Inhibitory concentration and cell type. Bar graph of $\mathrm{IC}_{50}$ values $(\mathrm{nM})$ and cell type. Cell lines are color coded by subtype: light blue, luminal; dark blue bars or stripes, HER2 amplified; yellow, nonluminal/undergone an epithelial-to-mesenchymal transition; red, nonluminal; turquoise, immortalized.

Full results of the ANOVA with the exact genes and Venn diagrams demonstrating the overlap between the cell classification markers and response markers are available online (see Additional data files 1, 2, and 3). Importantly, both MCF-10A and HCC-38 - sensitive cell lines that are of nonluminal origin - cluster with the remaining sensitive lines when this operation is performed excluding the subtype marker set (see Additional data file 4), highlighting the robustness of the predictive marker set.

\section{PD 0332991 inhibits pRb phosphorylation in sensitive cell lines}

It is known that CDK4/6 complexes with cyclin $D_{1}$ to phosphorylate and inactivate $\mathrm{pRb}$, thus allowing cell cycle progression. The effects of PD 0332991 on total pRb and Rb phosphorylation were determined using Western blot analysis of a subset of lines with variable sensitivities to PD 0332991.

There was no decrease in total $\mathrm{pRB}$ in either the sensitive group or the resistant group after treatment with the CDK4/6 inhibitor (Figure 3a). There were significant differences, however, in $\mathrm{Rb}$ phosphorylation when comparing sensitive and resistant cells after exposure to the compound. There was a rapid and sustained decrease in $\mathrm{pRb}$ with exposure to $100 \mathrm{nM}$ PD 0332991 in the three more sensitive cell lines (Figure 3b). The majority of the less sensitive lines have lower amounts of total $\mathrm{Rb}$, as determined by the microarray data; however, three resistant cell lines that have detectable $\mathrm{Rb}$ but are still resistant to PD 0332991 were also evaluated. These lines did not have a significant decrease in $\mathrm{Rb}$ phosphorylation with 100 nM PD 0332991.

\section{Effects of PD 0332991 on cell cycle and apoptosis}

To evaluate the effects of PD 0332991 on the cell cycle and to correlate them with the antiproliferative effects of the compound, we treated a subset of both sensitive cell lines and resistant cell lines with PD 0332991 at $100 \mathrm{nM}$ for 48 hours and then performed flow cytometry using Nim-DAPI staining. Clear and pronounced $G_{0} / G_{1}$ arrest was seen in cell lines that had lower $I_{50}$ values $\left(\mathrm{IC}_{50}<150 \mathrm{nM}\right)$ compared with those with higher $\mathrm{IC}_{50}$ values $\left(\mathrm{IC}_{50}>1,000 \mathrm{nM}\right)$ (Figure 4). There was no evidence of apoptosis in even the most sensitive cell lines when PD 0332991 was used as a single agent (data not shown).

Together, these data support a proposed cytostatic mechanism of action of this CDK4/6 inhibitor involving prevention of cell cycle progression by blocking hyperphosphorylation of $\mathrm{pRb}$.

\section{Combinations of PD 0332991 plus tamoxifen and PD 0332991 plus trastuzumab in ER-positive and HER2- amplified breast cancer cells, respectively}

Given that both the ER-positive cell lines as well as HER2amplified cell lines within the panel demonstrated greatest sensitivity to PD 0332991, the combination of targeted therapeutics plus the CDK4/6 inhibitor was evaluated in both of these molecular subtypes. In ER-positive breast cancer, hormonal blockade with tamoxifen is an effective treatment for early and advanced disease. For the three ER-positive lines evaluated, when considering the entire dose-response curve, the combination was synergistic with mean $\mathrm{Cl}<1$ across clinically relevant concentrations of both drugs (Figure 5a). Effects of the combination on the cell cycle are shown in Additional data file 5 . 
Table 1

Cell lines arranged from most sensitive (low IC ${ }_{50}$ ) to least sensitive (high IC ${ }_{50}$ )

\begin{tabular}{|c|c|c|c|c|c|}
\hline Cell line & $\mathrm{IC}_{50}$ value $(\mathrm{nM})$ & $\mathrm{IC}_{50}$ standard error & Breast cancer subtype & ER status & HER2 status \\
\hline MDA-MB-175 & 4 & 0.4 & Luminal & Positive & Normal \\
\hline ZR-75-30 & 5 & 0.5 & Luminal & Positive & Amplified \\
\hline CAMA-1 & 8 & 0.4 & Luminal & Positive & Normal \\
\hline MDA-MB-134 & 13 & 1.3 & Luminal & Positive & Normal \\
\hline HCC-202 & 21 & 2.3 & Luminal & Positive & Amplified \\
\hline UACC-893 & 24 & 1.6 & Luminal & Positive & Amplified \\
\hline EFM-19 & 27 & 12.3 & Luminal & Positive & Normal \\
\hline SUM-190 & 28 & 1.3 & Luminal & Positive & Amplified \\
\hline EFM-192A & 42 & 21.2 & Luminal & Positive & Amplified \\
\hline MDA-MB-361 & 44 & 4.1 & Luminal & Positive & Amplified \\
\hline HCC-1500 & 45 & 22.6 & Luminal & Positive & Normal \\
\hline HCC-1419 & 51 & 3.7 & Luminal & Positive & Amplified \\
\hline $\mathrm{HCC}-38$ & 64 & 14.8 & Basal & Negative & Normal \\
\hline MDA-MB-415 & 64 & 6.6 & Luminal & Positive & Normal \\
\hline MCF-10A & 92 & 0.1 & $\mathrm{n} / \mathrm{a}$ & Negative & Immortalized \\
\hline UACC-812 & 96 & 4.6 & Luminal & Positive & Amplified \\
\hline HCC-2218 & 100 & 17.0 & Luminal & Positive & Amplified \\
\hline ZR-75-1 & 110 & 54.1 & Luminal & Positive & Normal \\
\hline MDA-MB-453 & 115 & 1.4 & Luminal & Negative & Amplified \\
\hline $184 \mathrm{~A} 1$ & 118 & 2.0 & $\mathrm{n} / \mathrm{a}$ & Negative & Immortalized \\
\hline T47-D & 127 & 15.0 & Luminal & Positive & Normal \\
\hline MCF-7 & 148 & 25.7 & Luminal & Positive & Normal \\
\hline BT-20 & 177 & 3.1 & Basal & Negative & Normal \\
\hline MDA-MB-435 & 201 & 7.5 & Post-EMT & Negative & Normal \\
\hline BT-474 & 240 & 64.5 & Luminal & Positive & Amplified \\
\hline SK-BR-3 & 300 & 83.0 & Luminal & Negative & Amplified \\
\hline KPL-1 & 327 & 64.3 & Luminal & Positive & Normal \\
\hline HCC-1143 & 359 & 99.7 & Basal & Negative & Normal \\
\hline MDA-MB-231 & 432 & 16.1 & Post-EMT & Negative & Normal \\
\hline HCC-1395 & 472 & 39.8 & Post-EMT & Negative & Normal \\
\hline SUM-225 & 503 & 55.7 & Luminal & Negative & Amplified \\
\hline Hs578t & 524 & 12.3 & Post-EMT & Negative & Normal \\
\hline 184B5 & 538 & 41.1 & $\mathrm{n} / \mathrm{a}$ & Negative & Immortalized \\
\hline UACC-732 & 744 & 14.9 & Luminal & Positive & Amplified \\
\hline CAL-51 & 905 & 0.0 & Post-EMT & Negative & Normal \\
\hline BT-549 & 1,000 & $\mathrm{n} / \mathrm{a}$ & Post-EMT & Negative & Normal \\
\hline COLO-824 & 1,000 & $\mathrm{n} / \mathrm{a}$ & Basal & Negative & Normal \\
\hline DU4475 & 1,000 & $\mathrm{n} / \mathrm{a}$ & Basal & Negative & Normal \\
\hline HCC-1187 & 1,000 & $\mathrm{n} / \mathrm{a}$ & Basal & Negative & Normal \\
\hline HCC-1569 & 1,000 & $\mathrm{n} / \mathrm{a}$ & Post-EMT & Negative & Amplified \\
\hline HCC-1806 & 1,000 & $\mathrm{n} / \mathrm{a}$ & Basal & Negative & Normal \\
\hline HCC-1937 & 1,000 & $\mathrm{n} / \mathrm{a}$ & Post-EMT & Negative & Normal \\
\hline HCC-1954 & 1,000 & $\mathrm{n} / \mathrm{a}$ & Basal & Negative & Amplified \\
\hline $\mathrm{HCC}-70$ & 1,000 & $\mathrm{n} / \mathrm{a}$ & Basal & Negative & Normal \\
\hline MDA-MB-436 & 1,000 & $\mathrm{n} / \mathrm{a}$ & Post-EMT & Negative & Normal \\
\hline MDA-MB-157 & 1,000 & $\mathrm{n} / \mathrm{a}$ & Post-EMT & Negative & Normal \\
\hline MDA-MB-468 & 1,000 & $\mathrm{n} / \mathrm{a}$ & Basal & Negative & Normal \\
\hline
\end{tabular}

Included are molecular subtype and estrogen receptor (ER) and HER2 status. Cell lines representing the luminal ER-positive subtype were most sensitive to the growth inhibition effects of PD 0332991. n/a, not applicable; Post-EMT, cell lines classified as representing breast cancers that had undergone an epithelial-to-mesenchymal transition. 


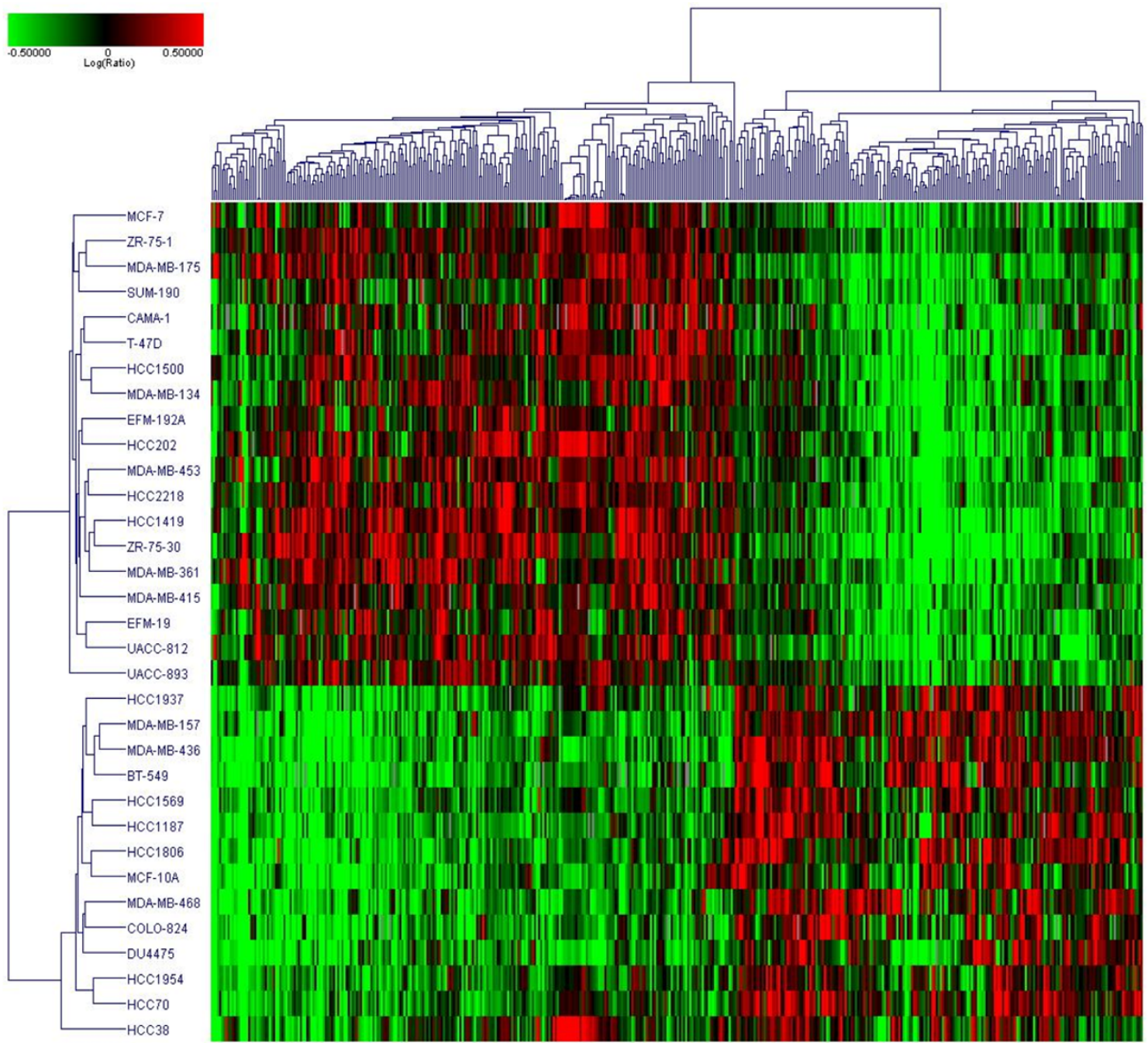

Differentially expressed genes between sensitive and resistant cell lines. Results of analysis of variance (ANOVA) identifying 450 differentially expressed genes between sensitive cell lines $\left(I C_{50}<150 \mathrm{nM}\right)$ and resistant cell lines $\left(I C_{50}>1,000 \mathrm{nM}\right)$. Retinoblastoma and cyclin $D_{1}$ expression were higher in, and CDKN2A ( 16 ) was lower in, sensitive cell lines. Full results of the ANOVA are available in the Additional data files.

Trastuzumab has been shown to have clinical activity in HER2amplified breast cancer [34]. For the three HER2-amplified lines evaluated, again when considering the entire doseresponse curve, the combination also proved to be synergistic with mean $\mathrm{Cl}<1$ across clinically relevant concentrations of both drugs (Figure 5b). Effects of the combination on the cell cycle are shown in Additional data file 6.

\section{PD 0332991 overcomes acquired resistance to tamoxifen}

The MCF7 tamoxifen-resistant cell line has acquired tamoxifen resistance after serial passages in estrogen-free conditions. These MCF7 tamoxifen-resistant cells demonstrated sensitivity to monotherapy with PD 0332991. Treatment with PD 0332991 also enhanced sensitivity to tamoxifen in the resistant cells when the two agents were used in combination, although not restoring them to the level of the parental line (Figure 6).

\section{Discussion}

The critical role of CDK-cyclin interactions in controlling cell growth has been an attractive target in cancer therapy for sometime. These data represent the most comprehensive preclinical evaluation of a CDK4/6 inhibitor in breast cancer cell lines to date, and build the case for its clinical development in specific molecular subgroups of breast cancer.

Using baseline Agilent gene expression profiles, we first demonstrated that luminal ER-positive and HER2-amplified breast cancer cell lines were more sensitive to CDK4/6 inhibition of proliferation and cell cycle arrest. ANOVA analysis of these data identified a set of genes that were associated with 


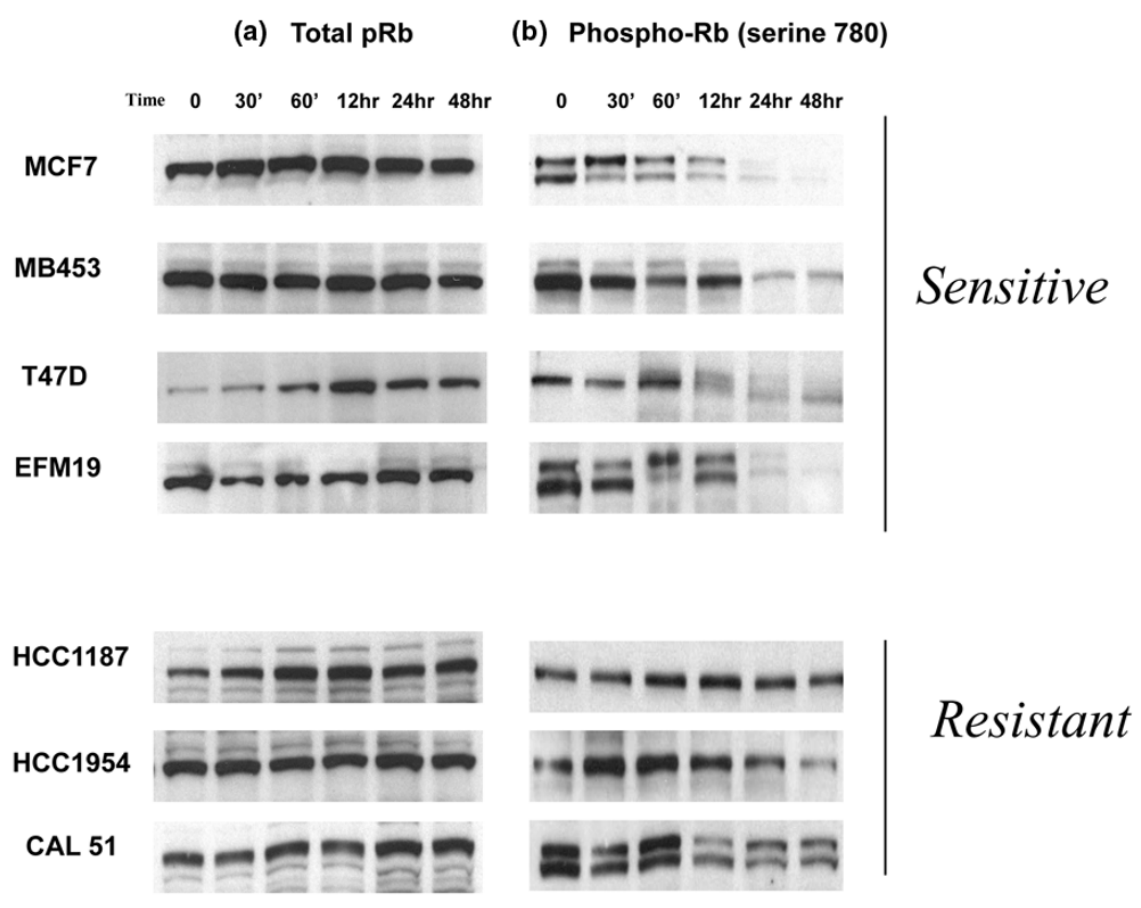

Effects of PD 0332991 on phosphorylation of retinoblastoma gene product. PD 0332991 blocks phosphorylation of retinoblastoma gene product $\mathrm{pRb}$ in sensitive cell lines but not in resistant cell lines. (a) In neither group does total pRb change significantly with treatment. (b) PD 0332991 significantly blocks phoshorylation of $\mathrm{pRb}$ (phospho-Rb) at serine 780 in sensitive cell lines $\left(\mathrm{IC}_{50}<150 \mathrm{nM}\right)$, but not in resistant cell lines $\left(\mathrm{IC}_{50}>1,000\right.$ $\mathrm{nM})$. All cell lines were treated with $100 \mathrm{nM}$ PD 0332991 for the times specified and western blots were performed as described in Materials and methods.

response to PD 0332991. While the majority of these genes were associated with the luminal subtype, increased RB1 and cyclin $D_{1}$ as well as decreased CDKN2A ( $\left.p 16\right)$ were associated with sensitivity to the effects of PD 0332991 on the cell cycle and growth inhibition. Western blot analysis confirmed that $\mathrm{Rb}$ phosphorylation is decreased in sensitive cell lines after PD 0332991 treatment, while resistant lines that had detectable $\mathrm{pRb}$ were relatively resistant to the effects of $\mathrm{PD}$ 0332991 on $\mathrm{Rb}$ phosphorylation. In this case, the presence of $\mathrm{pRb}$ alone is not predictive of response to PD 0332991. pRb presence in the background of luminal ER-positive breast cancer, however, is predictive of response to the compound. $\mathrm{pRb}$ is present in some nonluminal breast cancer cell lines but these lines are resistant to both the antiproliferative effects of PD 0332991 and its ability to block Rb hyperphosphorylation.

Further studies will be required to determine why PD 0332991 cannot block hyperphosphorylation in cell lines that do contain $\mathrm{pRb}$. One can speculate that potentially CDK4/6 is mutated in these cell lines and does not allow PD 0332991 binding and kinase inhibition, as is the case in resistance to BCR-ABL inhibitors in chronic myelogenous leukemia [35]. Alternatively, there may be another mechanism driving $\mathrm{Rb}$ hyperphosphorylation in resistant cell lines, such as a greater dependence on CDK1/2-cyclin E interactions or loss of negative regulators of this pathway in these cell lines.
Resistance to PD 0332991 in many of the nonluminal breast cancer cell lines may be explained by the absence of $p R b$. Recent publications highlighted the lack of $p R b$ in basal-like breast cancer tissue [36] and observed that $\mathrm{pRb}$ depletion can result in the characteristic epithelial-to-mesenchymal transition changes seen in some breast cancer specimens [37], recapitulating our in vitro observations. The lack of activity of a CDK4/6 inhibitor in cell lines and tumors that lack $p R b$ can be explained by the fact that cyclin $D_{1}$ does not offer $G_{1}$ control in the absence of $\mathrm{pRb}$ [38].

Published studies evaluating the role of cyclin $D_{1}$ in breast cancer support the current observations of the activity of a CDK4/ 6 inhibitor in luminal ER-positive breast cancer, its synergism with tamoxifen in cell lines that are sensitive to hormone manipulation, as well as the reversal of resistance of those that have acquired a resistant phenotype in the face of anti-estrogen therapy. Estrogen effects on cell cycle progression are tightly linked to expression of cyclin $D_{1}$ [39]. Cyclin $D_{1}$ amplification and/or overexpression has been more commonly associated with an ER-positive breast cancer subtype [40] and, as mentioned previously, is associated with tamoxifen resistance $[19,20]$. Some studies suggest that overexpression of cyclin $D_{1}$ can directly activate ER in a hormonally independent manner that is also independent of CDK and pRb function $[21,22]$. The data supporting this concept were reviewed recently [41]. 
Figure 4
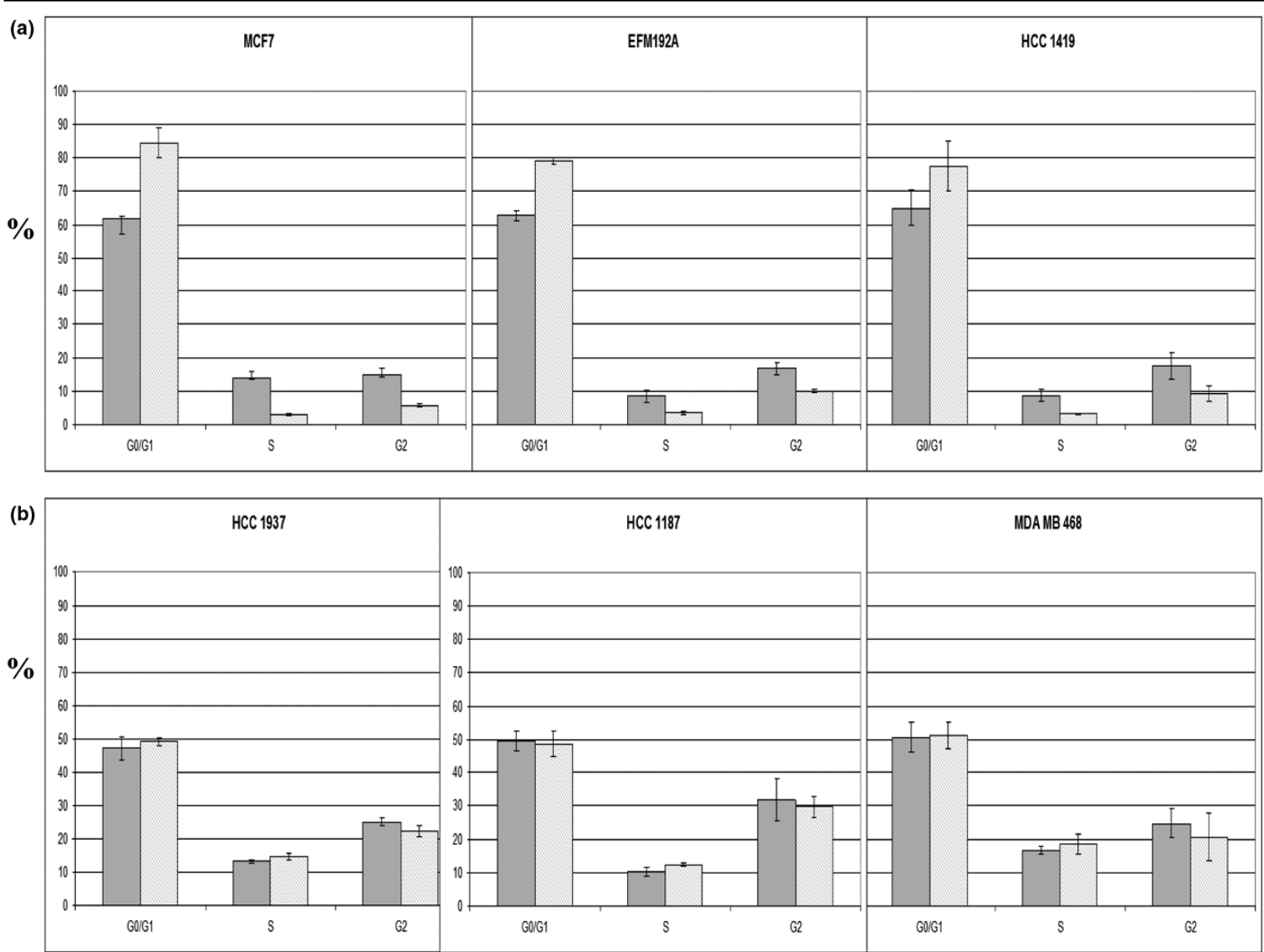

Effects of PD 0332991 on cell cycle. (a) Sensitive cell lines $\left(\mathrm{IC}_{50}<150 \mathrm{nM}\right)$ show marked $\mathrm{G}_{0} / \mathrm{G}_{1}$ arrest and a decrease in the S-phase fraction as compared with (b) resistant cell lines $\left(\mathrm{IC}_{50}>1,000 \mathrm{nM}\right)$ after incubation with $100 \mathrm{nM}$ PD 0332991 for 24 hours. Solid bars, control samples; hatched bars, treated samples. Error bars represent the standard error for two separate experiments.

In the large panel of human breast cancer lines we evaluated, however, 9/10 ER-positive lines were sensitive to PD 0332991 inhibition. Of interest, Wang and colleagues recently described a cyclin $D_{1}$ splice variant - named cyclin $D_{1 b}$ - that occurs in breast cancer tissue and cell lines, and whose expression can overcome cell cycle arrest induced by antiestrogens via a CDK4 interaction [42].

In addition, a pivotal role for cyclin $D_{1}$ function in HER2-mediated transformation has been described using transgenic mouse models [43]. More recently, the same authors defined that the ability of cyclin $D_{1}$ to activate CDK4 is critical for driving tumorigenesis in these models. Moreover, CDK4-associated kinase activity is required to maintain breast tumorigenesis in this system $[44,45]$ and a subset $(\sim 25 \%)$ of HER2-amplified breast cancers also have high cyclin $D_{1}$ levels. The authors hypothesized that this 'subset may benefit from inhibiting CDK4 kinase' [44]. Our data would suggest that the benefit with PD 0332991 might be extended beyond that $25 \%$, since the benefit was not dependent on elevated cyclin $D_{1}$ alone in the HER2-amplified cell lines. In addition, synergistic efficacy was observed between trastuzumab and PD 0332991 that may also be independent of cyclin $D_{1}$ measurement. Earlier work evaluating the nonspecific cyclin-CDK inhibitor flavopiridol in combination with trastuzumab also demonstrated similar activity in HER2-amplified cell lines [46]. Finally, a recent study investigating gene expression profiles of women with HER2-amplified breast cancer who develop early brain metastasis identified CDK4 expression as part of a 13gene profile that predicted for early brain metastasis and death [47].

Acquired and de novo resistance to trastuzumab remains a management challenge in clinical oncology. While limited data 
MCF7

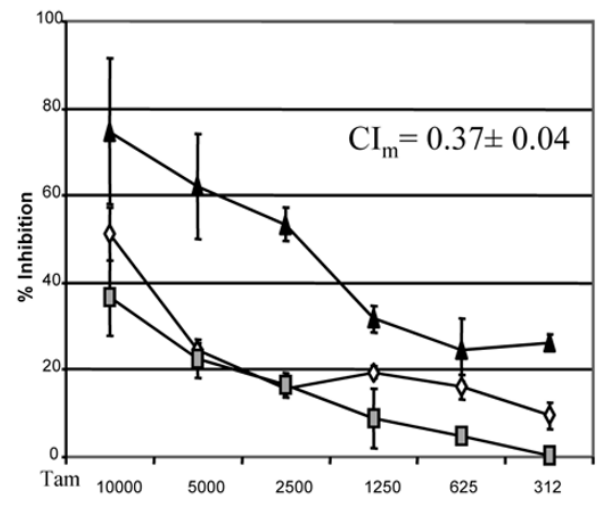

PD

Concentration (nM)

EFM19

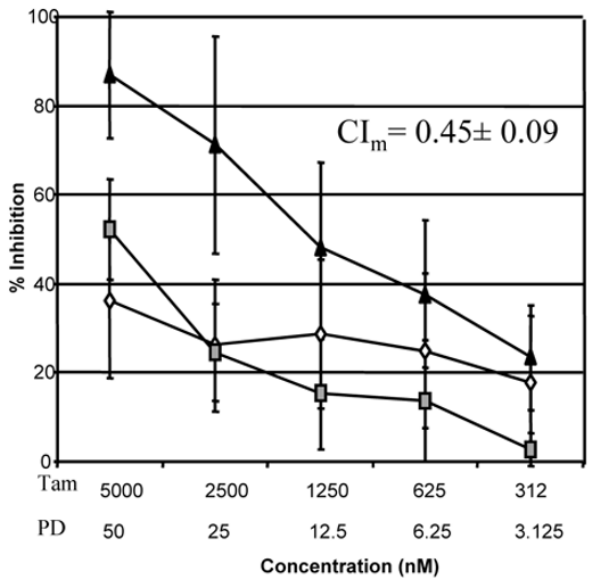

T47D

(a)

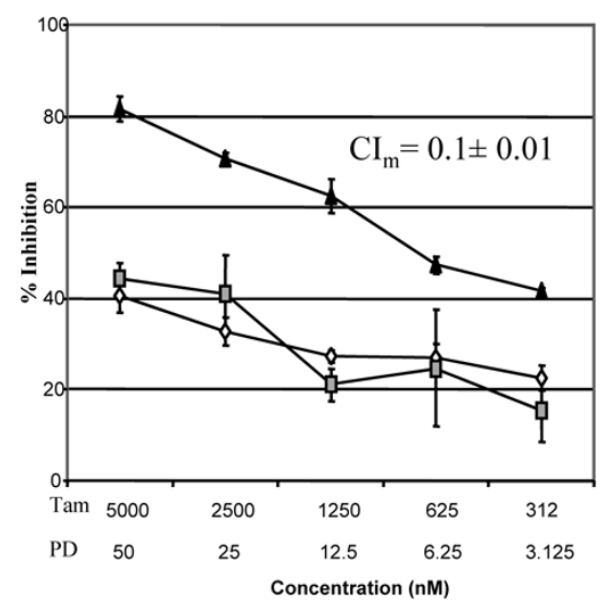

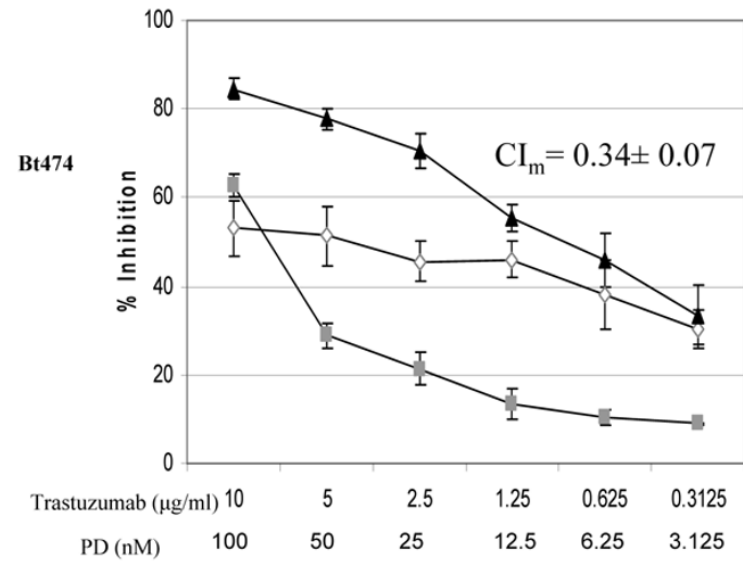

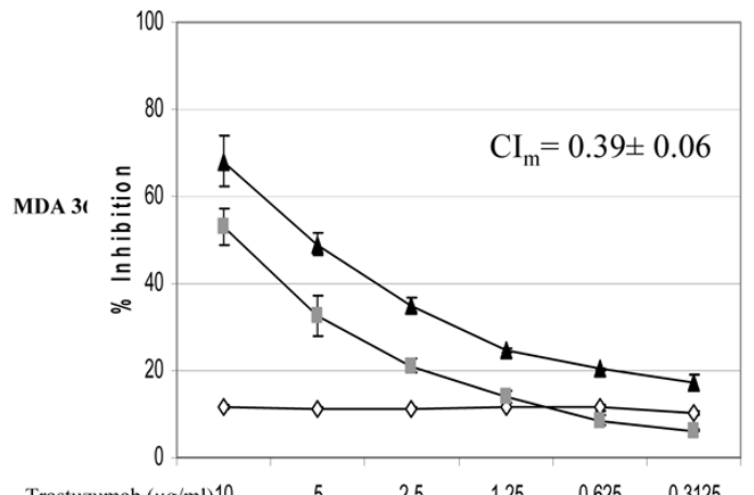

$\begin{array}{llllll}\text { Trastuzumab }(\mu \mathrm{g} / \mathrm{ml}) 10 & 5 & 2.5 & 1.25 & 0.625 & 0.3125\end{array}$

$\begin{array}{lllllll}\mathrm{PD}(\mathrm{nM}) & 100 & 50 & 25 & 12.5 & 6.25 & 3.125\end{array}$

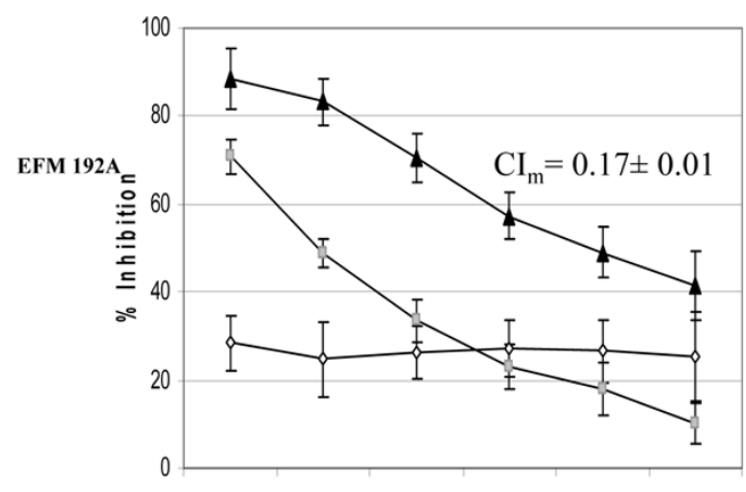

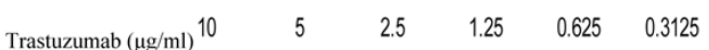

$\begin{array}{llllllll}\text { (b) } & \mathrm{PD}(\mathrm{nM}) & 100 & 50 & 25 & 12.5 & 6.25 & 3.125\end{array}$

Effects of PD 0332991, tamoxifen, and trastuzumab on growth of breast cancer cell lines. PD 0332991 (PD) acts synergistically with tamoxifen (Tam) and trastuzumab in inhibiting growth of (a) estrogen receptor-positive human breast cancer cell lines and (b) HER2-amplified cell lines in vitro, respectively. (a) Grey squares, PD 0332991 alone; open diamonds, tamoxifen alone; dark triangles, PD 0332991 and tamoxifen combination. (b) Grey squares, PD 0332991 alone; open diamonds, trastuzumab alone; dark triangles, PD 0332991 and trastuzumab combination. Error bars represent the standard error for two separate experiments. Mean combination index $\left(\mathrm{Cl}_{\mathrm{m}}\right)$ for the combination curves shown with standard error $\mathrm{Cl}_{\mathrm{m}}<1$, indicating synergy for the combinations. 
Figure 6

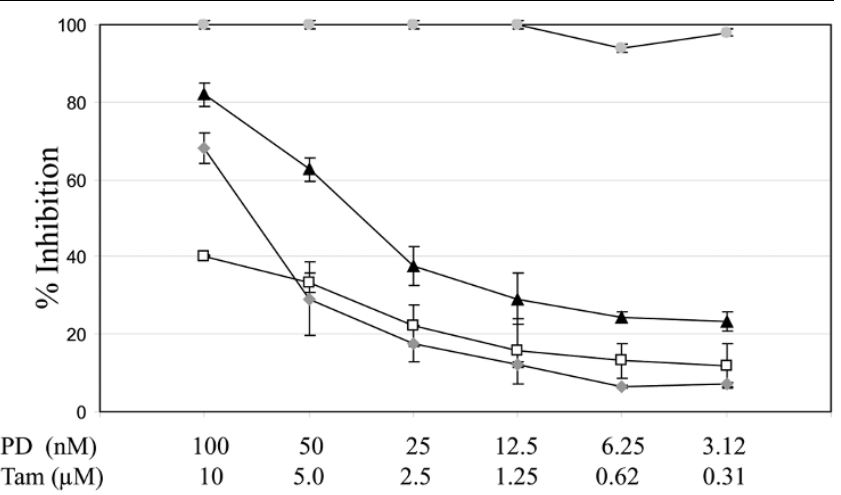

PD 0332991 and tamoxifen in a tamoxifen-insensitive cell line. PD 0332991 (PD) enhances the effects of tamoxifen (Tam) in an MCF7 tamoxifen-insensitive cell line. Dark triangles, PD 0332991 and tamoxifen combination; open squares, PD 0332991 alone; grey diamonds, tamoxifen alone; grey circles, MCF7 parental with tamoxifen alone. Error bars represent the standard error for two separate experiments. The MCF7 parental line is $100 \%$ inhibited under these conditions in the presence of tamoxifen (grey circles).

exist about the role of CDK4-cyclin $D_{1}$ interactions and trastuzumab resistance, these data suggest a role for dual targeting of the HER2 pathway and CDK4/6. Molecular profiling of the JIMT-1 human breast cancer cell line derived from a woman with progressive HER2-amplified disease while receiving trastuzumab did identify a small amplicon on $12 q 14.1$, which contains the CDK4 gene [48].

\section{Conclusions}

The goal of this preclinical study was to guide patient selection as this novel agent moves into the clinic. Given the data from the current study as well as published work, there is a strong rationale for clinical development of $P D 0332991$ focusing on ER-positive luminal breast cancer as well as HER2-amplified disease and combining CDK4/6 inhibition with anti-estrogen or anti-HER2 therapy, respectively.

\section{Competing interests}

RSF and DJS research funding from Pfizer, Inc. IC, CF, and GL are employees of Pfizer, Inc. The other authors declare that they have no competing interests.

\section{Authors' contributions}

RSF and DJS designed and supervised the study, analyzed data, and drafted the manuscript. JD performed data analysis. $\mathrm{DC}, \mathrm{OK}, \mathrm{DJC}$, and AD performed in vitro experiments and performed molecular biology. CG performed all microarrays and analyzed data. MA created the tamoxifen-resistant cell line and designed experiments. IC, CF, and GL collaborated in experimental design, data analysis, and manuscript writing. All authors read and approved the final manuscript.

\section{Additional files}

The following Additional files are available online:

\section{Additional file 1}

Excel file containing a table that lists the genes from the ANOVA of sensitive cell lines versus resistant cell lines. See http://www.biomedcentral.com/content/ supplementary/bcr2419-S1.XLS

\section{Additional file 2}

PowerPoint file containing a figure that shows a Venn diagram demonstrating the overlap between resistant and nonluminal markers in breast cancer cell lines.

See http://www.biomedcentral.com/content/ supplementary/bcr2419-S2.PPT

\section{Additional file 3}

PowerPoint file containing a figure that shows a Venn diagram demonstrating the overlap between sensitive and luminal markers in breast cancer cell lines.

See http://www.biomedcentral.com/content/ supplementary/bcr2419-S3.PPT

\section{Additional file 4}

PowerPoint file containing a figure that shows a cluster of differentially expressed genes between the sensitive and resistant cell lines that excludes genes associated with cell subtype.

See http://www.biomedcentral.com/content/ supplementary/bcr2419-S4.PPT

\section{Additional file 5}

PowerPoint file containing a figure that shows a cycle analysis of PD 0332991 in combination with tamoxifen. See http://www.biomedcentral.com/content/ supplementary/bcr2419-S5.PPT

\section{Additional file 6}

PowerPoint file containing a figure that shows a cycle analysis of PD 0332991 in combination with trastuzumab.

See http://www.biomedcentral.com/content/ supplementary/bcr2419-S6.PPT

\section{Acknowledgements}

RSF is a recipient of an NIH-LRP award. DJS received Department of Defense Innovator Award W81XWH-05-1-0395. The work is also funded by a gift to DJS by The Wittich Family Project for Emerging Therapies in Breast Cancer at UCLA's Jonsson Comprehensive Cancer Center. 


\section{References}

1. Jemal A, Siegel R, Ward E, Hao Y, Xu J, Murray T, Thun MJ: Cancer statistics, 2008. CA Cancer J Clin 2008, 58:71-96.

2. Perou CM, Sorlie T, Eisen MB, Rijn M van de, Jeffrey SS, Rees CA, Pollack JR, Ross DT, Johnsen H, Akslen LA, Fluge O, Pergamenschilkov A, Williams C, Zhu SX, Lonning PE, Borresen-Dale AL, Brown PO, Botstein D: Molecular portraits of human breast tumours. Nature 2000, 406:747-752.

3. Sorlie T, Perou CM, Tibshirani R, Aas T, Geisler S, Johnsen H, Hastie T, Eisen MB, Rijn M van de, Jeffrey SS, Thorsen T, Quist H, Matese JC, Brown PO, Botstein D, Eystein Lonning P, BorresenDale AL: Gene expression patterns of breast carcinomas distinguish tumor subclasses with clinical implications. Proc Natl Acad Sci USA 2001, 98:10869-10874.

4. Sotiriou C, Neo SY, McShane LM, Korn EL, Long PM, Jazaeri A, Martiat $P$, Fox SB, Harris AL, Liu ET: Breast cancer classification and prognosis based on gene expression profiles from a population-based study. Proc Natl Acad Sci USA 2003, 100:10393-10398.

5. Hanahan D, Weinberg RA: The hallmarks of cancer. Cell 2000, 100:57-70.

6. Swanton C: Cell-cycle targeted therapies. Lancet Oncol 2004, 5:27-36.

7. Lundberg AS, Weinberg RA: Control of the cell cycle and apoptosis. Eur J Cancer 1999, 35:1886-1894.

8. Caldon CE, Daly RJ, Sutherland RL, Musgrove EA: Cell cycle control in breast cancer cells. J Cell Biochem 2006, 97:261-274.

9. Sutherland RL, Musgrove EA: Cyclins and breast cancer. J Mammary Gland Biol Neoplasia 2004, 9:95-104.

10. Buckley MF, Sweeney KJ, Hamilton JA, Sini RL, Manning DL, Nicholson RI, deFazio A, Watts CK, Musgrove EA, Sutherland RL: Expression and amplification of cyclin genes in human breast cancer. Oncogene 1993, 8:2127-2133.

11. Dickson C, Fantl V, Gillett C, Brookes S, Bartek J, Smith R, Fisher C, Barnes D, Peters G: Amplification of chromosome band $11 \mathrm{q} 13$ and a role for cyclin $D_{1}$ in human breast cancer. Cancer Lett 1995, 90:43-50.

12. Bartkova J, Lukas J, Muller H, Lutzhoft D, Strauss M, Bartek J: Cyclin $D_{1}$ protein expression and function in human breast cancer. Int J Cancer 1994, 57:353-361.

13. Gillett C, Fantl V, Smith R, Fisher C, Bartek J, Dickson C, Barnes D, Peters G: Amplification and overexpression of cyclin D1 in breast cancer detected by immunohistochemical staining. Cancer Res 1994, 54:1812-1817.

14. Kenny FS, Hui R, Musgrove EA, Gee JM, Blamey RW, Nicholson $\mathrm{RI}$, Sutherland RL, Robertson JF: Overexpression of cyclin $\mathrm{D}_{1}$ messenger RNA predicts for poor prognosis in estrogen receptor-positive breast cancer. Clin Cancer Res 1999, 5:2069-2076.

15. Stendahl M, Kronblad A, Ryden L, Emdin S, Bengtsson NO, Landberg $G$ : Cyclin $D_{1}$ overexpression is a negative predictive factor for tamoxifen response in postmenopausal breast cancer patients. Br J Cancer 2004, 90:1942-1948.

16. McIntosh GG, Anderson JJ, Milton I, Steward M, Parr AH, Thomas $\mathrm{MD}$, Henry JA, Angus B, Lennard TW, Horne $\mathrm{CH}$ : Determination of the prognostic value of cyclin $D_{1}$ overexpression in breast cancer. Oncogene 1995, 11:885-891.

17. Gillett C, Smith $P$, Gregory W, Richards M, Millis R, Peters G, Barnes $D$ : Cyclin $D_{1}$ and prognosis in human breast cancer. Int $J$ Cancer 1996, 69:92-99.

18. Hwang TS, Han HS, Hong YC, Lee HJ, Paik NS: Prognostic value of combined analysis of cyclin $D_{1}$ and estrogen receptor status in breast cancer patients. Pathol Int 2003, 53:74-80.

19. Rudas M, Lehnert M, Huynh A, Jakesz R, Singer C, Lax S, Schippinger W, Dietze O, Greil R, Stiglbauer W, Kwasny W, Grill R, Stierer M, Gnant MF, Filipits M: Cyclin $D_{1}$ expression in breast cancer patients receiving adjuvant tamoxifen-based therapy. Clin Cancer Res 2008, 14:1767-1774.

20. Jirstrom K, Stendahl M, Ryden L, Kronblad A, Bendahl PO, Stal O, Landberg G: Adverse effect of adjuvant tamoxifen in premenopausal breast cancer with cyclin $D_{1}$ gene amplification. Cancer Res 2005, 65:8009-8016.

21. Zwijsen RM, Wientjens E, Klompmaker R, Sman J van der, Bernards R, Michalides RJ: CDK-independent activation of estrogen receptor by cyclin $\mathrm{D}_{1}$. Cell 1997, 88:405-415.
22. Neuman E, Ladha MH, Lin N, Upton TM, Miller SJ, DiRenzo J, Pestell RG, Hinds PW, Dowdy SF, Brown M, Ewen ME: Cyclin D stimulation of estrogen receptor transcriptional activity independent of cdk4. Mol Cell Biol 1997, 17:5338-5347.

23. Bosco EE, Knudsen ES: RB in breast cancer: at the crossroads of tumorigenesis and treatment. Cell Cycle 2007, 6:667-671.

24. McClue SJ, Blake D, Clarke R, Cowan A, Cummings L, Fischer PM, MacKenzie M, Melville J, Stewart K, Wang S, Zhelev N, Zheleva D, Lane DP: In vitro and in vivo antitumor properties of the cyclin dependent kinase inhibitor CYC202 (R-roscovitine). Int J Cancer 2002, 102:463-468.

25. Misra RN, Xiao HY, Kim KS, Lu S, Han WC, Barbosa SA, Hunt JT, Rawlins DB, Shan W, Ahmed SZ, Qian L, Chen BC, Zhao R, Bednaz MS, Kellar KA, Mulheron JG, Batorsky R, Roongta U, Kamath A, Marathe P, Ranadive SA, Sack JS, Tokarski JS, Pavletich NP Lee FY, Webster KR, Kimball SD: $N$-(cycloalkylamino)acyl-2aminothiazole inhibitors of cyclin-dependent kinase 2. N-[5[[[5-(1,1-dimethylethyl)-2-oxazolyl]methyl]thio]-2-thiazolyl]4-piperidinecarboxamide (BMS-387032), a highly efficacious and selective antitumor agent. J Med Chem 2004, 47:1719-1728.

26. Fry DW, Harvey PJ, Keller PR, Elliott WL, Meade M, Trachet E, Albassam M, Zheng X, Leopold WR, Pryer NK, Toogood PL: Specific inhibition of cyclin-dependent kinase 4/6 by PD 0332991 and associated antitumor activity in human tumor xenografts. Mol Cancer Ther 2004, 3:1427-1438.

27. Toogood PL, Harvey PJ, Repine JT, Sheehan DJ, VanderWel SN Zhou H, Keller PR, McNamara DJ, Sherry D, Zhu T, Brodfuehrer J, Choi C, Barvian MR, Fry DW: Discovery of a potent and selective inhibitor of cyclin-dependent kinase 4/6. J Med Chem 2005, 48:2388-2406.

28. Marzec M, Kasprzycka M, Lai R, Gladden AB, Wlodarski P, Tomczak E, Nowell P, Deprimo SE, Sadis S, Eck S, Schuster SJ, Diehl JA, Wasik MA: Mantle cell lymphoma cells express predominantly cyclin $D_{10}$ isoform and are highly sensitive to selective inhibition of CDK4 kinase activity. Blood 2006, 108:1744-1750.

29. Saab R, Bills JL, Miceli AP, Anderson CM, Khoury JD, Fry DW, Navid F, Houghton PJ, Skapek SX: Pharmacologic inhibition of cyclin-dependent kinase 4/6 activity arrests proliferation in myoblasts and rhabdomyosarcoma-derived cells. Mol Cancer Ther 2006, 5:1299-1308.

30. Baughn LB, Di Liberto M, Wu K, Toogood PL, Louie T, Gottschalk $\mathrm{R}$, Niesvizky R, Cho H, Ely S, Moore MA, Chen-Kiang S: A novel orally active small molecule potently induces $G_{1}$ arrest in primary myeloma cells and prevents tumor growth by specific inhibition of cyclin-dependent kinase 4/6. Cancer Res 2006, 66:7661-7667.

31. Neve RM, Chin K, Fridlyand J, Yeh J, Baehner FL, Fevr T, Clark L, Bayani N, Coppe JP, Tong F, Speed T, Spellman PT, DeVries S, Lapuk A, Wang NJ, Kuo WL, Stilwell JL, Pinkel D, Albertson DG, Waldman FM, McCormick F, Dickson RB, Johnson MD, Lippman M, Ethier S, Gazdar A, Gray JW: A collection of breast cancer cell lines for the study of functionally distinct cancer subtypes. Cancer Cell 2006, 10:515-527.

32. Finn RS, Dering J, Ginther C, Wilson CA, Glaspy P, Tchekmedyian $\mathrm{N}$, Slamon DJ: Dasatinib, an orally active small molecule inhibitor of both the src and abl kinases, selectively inhibits growth of basal-type/'triple-negative' breast cancer cell lines growing in vitro. Breast Cancer Res Treat 2007, 105:319-326.

33. Chou TC, Talalay P: Quantitative analysis of dose-effect relationships: the combined effects of multiple drugs or enzyme inhibitors. Adv Enzyme Regul 1984, 22:27-55.

34. Slamon DJ, Leyland-Jones B, Shak S, Fuchs H, Paton V, Bajamonde A, Fleming T, Eiermann W, Wolter J, Pegram M, Baselga J, Norton L: Use of chemotherapy plus a monoclonal antibody against HER2 for metastatic breast cancer that overexpresses HER2. N Engl J Med 2001, 344:783-792.

35. Shah NP, Nicoll JM, Nagar B, Gorre ME, Paquette RL, Kuriyan J, Sawyers CL: Multiple BCR-ABL kinase domain mutations confer polyclonal resistance to the tyrosine kinase inhibitor imatinib (STI571) in chronic phase and blast crisis chronic myeloid leukemia. Cancer Cell 2002, 2:117-125.

36. Gauthier ML, Berman HK, Miller C, Kozakeiwicz K, Chew K, Moore D, Rabban J, Chen YY, Kerlikowske K, TIsty TD: Abrogated response to cellular stress identifies DCIS associated with 
subsequent tumor events and defines basal-like breast tumors. Cancer Cell 2007, 12:479-491.

37. Arima $Y$, Inoue $Y$, Shibata $T$, Hayashi H, Nagano O, Saya H, Taya $\mathrm{Y}$ : $\mathrm{Rb}$ depletion results in deregulation of $\mathrm{E}$-cadherin and induction of cellular phenotypic changes that are characteristic of the epithelial-to-mesenchymal transition. Cancer Res 2008, 68:5104-5112.

38. Lukas J, Bartkova J, Rohde M, Strauss M, Bartek J: Cyclin $D_{1}$ is dispensable for $G_{1}$ control in retinoblastoma gene-deficient cells independently of cdk4 activity. Mol Cell Biol 1995, 15:2600-2611.

39. Butt AJ, McNeil CM, Musgrove EA, Sutherland RL: Downstream targets of growth factor and oestrogen signalling and endocrine resistance: the potential roles of c-Myc, cyclin $\mathrm{D}_{1}$ and cyclin E. Endocr Relat Cancer 2005, 12(Suppl 1):S47-S59.

40. Zukerberg LR, Yang WI, Gadd M, Thor AD, Koerner FC, Schmidt EV, Arnold A: Cyclin $D_{1}$ (PRAD1) protein expression in breast cancer: approximately one-third of infiltrating mammary carcinomas show overexpression of the cyclin $D_{1}$ oncogene. Mod Pathol 1995, 8:560-567.

41. Arnold A, Papanikolaou A: Cyclin $D_{1}$ in breast cancer pathogenesis. J Clin Oncol 2005, 23:4215-4224.

42. Wang Y, Dean JL, Millar EK, Tran TH, McNeil CM, Burd CJ, Henshall SM, Utama FE, Witkiewicz A, Rui H, Sutherland RL, Knudsen $K E$, Knudsen ES: Cyclin $D_{1 b}$ is aberrantly regulated in response to therapeutic challenge and promotes resistance to estrogen antagonists. Cancer Res 2008, 68:5628-5638.

43. Yu Q, Geng $Y$, Sicinski P: Specific protection against breast cancers by cyclin $D_{1}$ ablation. Nature 2001, 411:1017-1021.

44. Yu Q, Sicinska E, Geng Y, Ahnstrom M, Zagozdzon A, Kong Y, Gardner H, Kiyokawa H, Harris LN, Stal O, Sicinski P: Requirement for CDK4 kinase function in breast cancer. Cancer Cell 2006, 9:23-32

45. Reddy HK, Mettus RV, Rane SG, Grana X, Litvin J, Reddy EP: Cyclin-dependent kinase 4 expression is essential for neuinduced breast tumorigenesis. Cancer Res 2005, 65:10174-10178.

46. Wu K, Wang C, D'Amico M, Lee RJ, Albanese C, Pestell RG, Mani $\mathrm{S}$ : Flavopiridol and trastuzumab synergistically inhibit proliferation of breast cancer cells: association with selective cooperative inhibition of cyclin $D_{1}$-dependent kinase and Akt signaling pathways. Mol Cancer Ther 2002, 1:695-706.

47. Duchnowska RJJ, Thorat MA, Morimiya A Sledge GW, Li L, Biernat W, Szczylik C, Steeg PS, Badve SS: Gene expression analysis for prediciton of early brain metastasis in HER2-positive breast cancer patients [abstract 1019]. J Clin Onco/ 2008, 26(20 Suppl): abstract 1019

48. Rennstam K, Jonsson G, Tanner M, Bendahl PO, Staaf J, Kapanen Al, Karhu R, Baldetorp B, Borg A, Isola J: Cytogenetic characterization and gene expression profiling of the trastuzumabresistant breast cancer cell line JIMT-1. Cancer Genet Cytogenet 2007, 172:95-106. 